\title{
Political Fragmentation and Projected Tax Revenues : Evidence from Flemish Municipalities
}

\author{
Stijn Goeminne ${ }^{\mathrm{a}}$ *, Benny Geys ${ }^{\mathrm{b}}{ }^{*}$ and Carine Smolders ${ }^{\mathrm{a}}$ \\ a Department of Business Administration and Public Management, Hogeschool Gent, Voskenslaan \\ 270, B-9000 Ghent, Belgium; e-mail: stijn.goeminne@hogent.be, carine.smolders@hogent.be \\ b Wissenschaftszentrum Berlin für Sozialforschung (WZB), Reichpietschufer 50, \\ D-10785 Berlin, Germany; e-mail: geys@wz-berlin.de
}

\begin{abstract}
The level of revenues pocketed by a government during the fiscal year often deviates from that projected by this government in its budget. Though this difference between actual and projected revenues is not always negligible, little is yet known about what may explain such forecast errors. In the present paper, we analyse whether differences in the level of government fragmentation are useful in explaining local government tax revenue forecast errors - controlling for various other factors. Using data on 242 Flemish municipalities for the period 1992-2002, we find that two-party governments are more optimistic than single-party governments. In contrast to our initial expectations, governments with at least three parties are significantly more careful (or less optimistic) in their revenue projections than single- or two-party governments.
\end{abstract}

JEL-codes: D72, H72, H79

Keywords: tax projections, forecast accuracy, Flemish municipalities, government fragmentation.

* Corresponding author: Stijn Goeminne, e-mail: stijn.goeminne@hogent.be, Tel: +32 9248 88 34, Fax: +32 9 24242 09. The authors are grateful to Bruno Heyndels, Jan Vermeir and participants of participants of the $61^{\text {st }}$ IIPF Meeting (Korea); VVE-dag (Brussels, Belgium) and a research seminar at WZB (Berlin, Germany) for helpful comments on a previous version of this paper. We gratefully acknowledge the financial support of the Flemish Government (Steunpunt Bestuurlijke Organisatie Vlaanderen (SBOV)) 


\section{Introduction}

Theoretical and empirical research shows that differences in the political and institutional characteristics of governments are important determinants of the (fiscal) policies they (fail to) pursue. A central role in this respect is often given to government fragmentation, that is, to the extent in which power is dispersed over different parties or politicians. For example, in their path-breaking work, Roubini and Sachs (1989a, b) show that weaker (i.e. more fragmented) governments tend to face larger budget deficits and debts. The lack of (fiscal) austerity in fragmented governments is often explained by pointing to their higher spendthrift. Compared to one-party governments, fragmented governments tend to have higher spending levels, which leads to their inferior budgetary outcomes (e.g. Volkerink and de Haan, 2001 and Perotti and Kontopoulos, 2002). In the present paper, we focus on the revenue rather than the expenditure side. Moreover, we take the analysis one step back by looking at government behaviour at the time of drafting the budget (instead of concentrating exclusively on actual spending or revenue data). Specifically, we examine whether fragmented governments tend to be systematically more optimistic (than one-party governments) about expected revenue levels. Such behaviour leads to negative budgetary 'surprises' during the fiscal year and 'unexpected' deficits post hoc, thus providing an alternative explanation for the higher budget deficits of fragmented governments.

Three possible reasons can be advanced why government fragmentation would lead to more optimistic revenue forecasts. Firstly, highly fragmented governments facing a balanced budget requirement and the impossibility to spend money that was not entered into the budget (such as is the case at the Belgian local government level) can help accommodate their higher spendthrift by an 'optimistic bias'. Indeed, "some commentators have suggested that budget estimates are inherently sensitive to political pressures which, it is presumed, sacrifice accuracy in order to mitigate the need to undertake program cuts” (Plesko, 1988, 483). Secondly, though related to the first point, a rosy estimate may facilitate decision-making on the budget. As reaching agreement is more difficult under highly fragmented governments, easing the 'war of attrition' (cfr. Alesina and Drazen, 1991) through optimistic assessments of future revenues may be most needed under such circumstances. Finally, when parties fear to lose their position in the ruling majority after upcoming elections, they may want to curtail the policy options of their successors by incurring fiscal deficits and debts (cfr. "strategic use of debt" models by Persson and Svensson, 1989; Alesina and Tabellini, 1990 and Tabellini and Alesina, 1990). As parties in a coalition government are likely to be less certain about future power than one-party governments, they may have a larger incentive to be (over)optimistic with respect to budgeted revenues (thereby creating fiscal deficits post hoc and restricting the options of future governments).

We are not the first to regard the accuracy of the government's budget forecasts. Plesko (1988) and Auerbach (1995; 1999) study the accuracy of government budget forecasts using U.S. federal data while Bischoff (2004) regards tax revenue projections of German Länder. In addition, several scholars indirectly analyse the gap between budgeted and actual revenues by considering the adequacy of tax collecting bodies using a tax technology function (e.g. Mayshar, 1991; Hunter and Nelson, 1995; Young et al., 2001; Esteller-Moré, 2004). Still, these studies have neglected the possible effect of government fragmentation. Hence, in the present paper, we wish to gain further insights into the effects of government fragmentation on political decision-making and into the determinants of (local) government revenue forecast bias using a panel dataset on 242 Flemish municipalities for the period 19922002.

The remainder of the paper is structured as follows. Section 2 reviews the literature on (revenue) projection errors and presents the theoretical basis for our main research hypotheses. The Flemish institutional background is clarified in section 3 . Section 4 
introduces the empirical analysis. The main findings of the paper are summarized in section 5 .

\section{Literature and hypotheses}

What can explain the deviation of actual revenues from those forecasted? Clearly, under- or overestimation of revenues can be due to inadequate forecasting, inefficient revenue collection or both. Hence, to explain revenue forecast errors, we must determine the elements that undermine the government's ability and willingness to make adequate assessments of their future revenue streams and/or those that lead to inefficient revenue collection. Most authors studying the quality of tax projections mainly point to the influence of the technical aspects of the tax collection and budgeting process. These elements are discussed in sections 2.1 and 2.2 respectively. However, in this paper, we draw attention more explicitly to the effect of political-institutional characteristics of governments - and especially their level of fragmentation. Do fragmented governments estimate their revenues differently from oneparty governments? These political economy explanations of tax forecast bias are more extensively considered in section 2.3.

\subsection{The tax collection process}

Revenue projections may be above actually pocketed revenue levels when the tax administration fails to adequately collect the tax liabilities. As such, revenue forecast bias is related to tax administration performance. In this view, tax-collecting bodies are expected to garner the maximum possible amount of tax liabilities. The extent to which they succeed in this depends on the tax technology function. Mayshar (1991) identifies the major components of this tax technology function. In his (formal) model, the level of collected tax revenues is a function of the number of tax inspectors and general staff, the stock of capital and the marginal statutory tax rate. While the first two elements are likely to increase the amount of revenues collected, the last component is likely to decrease tax collections (due to a higher effort on the part of taxpayers to evade payment of their taxes).

More recent research introduces variables measuring the tax administration's efforts to reduce tax non-compliance. Esteller-Moré (2004), for example, finds that the administration's effort to collect taxes depends on the budgetary situation of the government and on the significance of grant income. Spanish regional governments more actively engage in enforcing tax rules when facing or expecting a larger deficit. When, on the other hand, the share of unconditional grants in total revenues increases, regional efforts to collect taxes decrease. Moreover, the strength of tax rule enforcement might also be guided by electoral concerns. For example, Young et al. $(2001,201)$ report "the fraction of individual income tax returns audited [by the IRS] is significantly lower in districts that are important to the president electorally and that have representation on key congressional committees". This supports the finding of Hunter and Nelson $(1995,53)$ that the IRS "shifts enforcement away from states represented by legislators who sit on committees with oversight responsibility for the IRS”.

\subsection{Incomplete information in the budgeting process}

Deviations from projected tax revenues may also result from building revenue forecasts on (what turn out to be) erroneous assumptions. This can first of all arise from unpredictable changes in tax laws after the budget was made up (Plesko, 1988 and Auerbach, 1995). Next to such policy-related errors, the American Congressional Budget Office (CBO) 
and the Office of Management and Budget (OMB) distinguish between economic and technical errors (CBO, 1997). Economic errors are those attributable to inaccurate forecasts of macroeconomic variables (i.e. economic growth, inflation, unemployment, interest rates). Technical errors are residual forecast errors. ${ }^{1}$ Technical revisions might be necessary because of changing tax compliance behaviour, tax base mobility, shifts between income categories or changes in the distribution of income. The impact of these sources of forecast error depends, however, on the way they are related to the tax portfolio. As far as the uncertainty about, say, tax base mobility is specific to a given tax ('idiosyncratic risk'), diversification of the tax portfolio might be a useful strategy to accommodate this problem. Yet, governments are also facing general shocks (e.g. war, economic slowdown, disasters, ...), which affect tax revenues generally. In contrast to the former idiosyncratic risks, tax structure diversification does little to abate these risks. ${ }^{2}$

Little is known about the importance of these various types of forecasting errors. Plesko (1988) examines the record of accuracy of the receipts, outlays and deficit estimates of the two American budget-forecasting offices (CBO and OMB) over the period 1974-1987. He finds a sharp rise in the mean forecast errors when the time horizon of the forecast increases. Forecasts of events further in the future are significantly worse than short-term predictions. He attributes this mostly to policy-related errors. Auerbach (1995) studies forecast errors for aggregate revenues as well as for specific taxes using a US time series covering the period 1982-1993. He rather points to the inadequate estimate of taxpayer responses to the government's tax initiatives (or technical errors).

Importantly, given that the tax administration projects revenues starting from incomplete information, the outcome also depends on the risk attitude of the decision makers. In other words, the quality of the forecast (and thus the size and direction of the forecast error) is related to the government's risk aversion and the actual occurrence of a disruptive event. If the government is risk averse, it is likely to assume the event will take place and lowers its revenue forecast accordingly. In case the event actually takes place the budget balances; if it does not, the returns are underestimated. Risk-loving decision-makers on the contrary are likely to disregard the possible occurrence of the disruptive event. When the event occurs, revenues are overestimated, while in the absence of the event the projections are correct.

\subsection{Political fragmentation and revenue projection bias}

The previous two explanations argue that forecasting errors result from the government's limited information or sub-optimal tax collection efforts. Yet, even in case of perfectly informed governments and optimal performance of tax administrations, tax projections might still not be accurate. In the remainder of this section, we argue that politicalinstitutional characteristics of the government - and especially its level of fragmentation may affect (or incite) revenue forecast errors. More specifically, we hypothesize that fragmented governments are susceptible to be more optimistic about future revenues.

\section{The weak government / common pool-hypothesis}

Over the past 15 years, a growing body of empirical evidence has developed in support of the "Weak Government Hypothesis" (WGH; Roubini and Sachs, 1989a, b). This hypothesis states that weaker - i.e. more fragmented - governments tend to follow less restrictive fiscal policies leading to higher levels of expenditures as well as higher debts and

1 Auerbach (1999) rightly states that the distinction between economic and technical errors is somewhat arbitrary. For example, revisions to macroeconomic forecasts that are anticipated at the time of revenue forecasting but are not yet official may be incorporated as a technical element.

2 This relates to the difference between the risk related to an individual asset and the risk affecting the market as a whole in portfolio management theory (in financial economics). 
deficits (for recent evidence, see Ricciuti, 2004; Rumi, 2004 and Borge, 2005; for a review, see Ashworth et al., 2005a). The reason is that governments rely on a 'common pool' of resources to finance their policies while the benefits of expenditure programs can be targeted at specific groups (Tullock, 1959; Weingast et al., 1981). Consequently, whereas the benefits are fully appropriated by these groups, they only internalise part of the costs of the expenditure programs. This leads to an expenditure-bias and - in a dynamic setting - to a deficit-bias (Velasco, 1999, 2000).

To the best of our knowledge, no attention has yet been awarded to the relation between government fragmentation and tax projection bias. Still, since higher expenditure levels are expected under fragmented governments, they need more revenues to finance these and may thus be tempted to be more optimistic in their projections. Note, moreover, that this effect is likely to be especially strong in our setting (i.e. the Flemish municipalities) due to two important restrictions on local budgetary decision-making. Firstly, no expenses are allowed unless they are written into the municipality's budget. Hence, to execute an expenditure plan in year $t$, these costs must be taken up in the budget that is drafted in year t1. Secondly, Flemish municipalities are obliged to present a balanced budget. These two elements entail that the heightened level of expenditures in fragmented governments must also show from the budget they drafted at $\mathrm{t}-1$. Therefore, and to satisfy the statutory regulation to balance the budget, this is likely to create a more pressing need for these governments to be (overly?) optimistic about future revenues while drafting the budget. Indeed, such an optimistic estimation of local tax revenues allows them to implement a higher level of expenditures at time $t$ at a lower political cost in terms of votes lost at election time (at least in the short term) compared to an increase in taxation. As politicians can be expected to act in a way to minimize the political costs of their actions (see e.g. Hettich and Winer, 1984, 1988), over-estimation of future revenues is more likely to occur than, say, increases in tax rates. ${ }^{3}$

It is important to note here that we do not impose an explicit objective by fragmented governments to consciously overestimate tax revenues to accommodate their higher expenditures. The politicians drafting the budget may well believe in achieving the budgeted level of tax revenue. Indeed, the 'cognitive dissonance' literature argues that people have preferences over their states of beliefs and select sources of information to confirm these 'desired beliefs' (see e.g. Akerlof and Dickens, 1982). In other words, people like to believe what they want to be the(ir) truth. Or, in our story, politicians desire a certain level of tax revenue (which is higher for fragmented governments) and they are convinced to realize (at least) that level of revenues. This conviction is built on arguments that support the achievement of this revenue level while other arguments that reject these beliefs are disregarded.

\section{War of attrition}

In their pioneering work, Alesina and Drazen (1991) model fiscal decisions within coalition governments as a stabilization process in which each group of the coalition attempts to wait the others out. They assume a negative (exogenous) shock that deteriorates the government's budgetary situation. Crucially, Alesina and Drazen (1991) argue that a delay in the required stabilization process occurs in fragmented governments as all parties may well agree on the need for a reform, but probably disagree on how the burden of the reform is divided. Each party has an incentive to wait until the others capitulate, so they can pass the largest part of the negative effects of the decision to the other parties (and their electorate). The lower the degree of political cohesion (or, the more fragmented the government), the later

3 Poterba (1994) also explicitly points to the use of such 'cosmetic accounting' to satisfy balanced-budget rules. For an overview of the impact of balanced-budget rules on fiscal policies, see Poterba (1995). 
is the expected date of stabilization. ${ }^{4}$ Supportive evidence of this 'war of attrition' model is provided by Poterba (1994) and Alt and Lowry (1994). Indeed, they show that unified governments "are more likely to respond quickly" to fiscal shocks than divided governments (Poterba, 1994, 818).

This idea of different parties struggling to reach agreement over (fiscal) policy decisions can straightforwardly be applied to the analysis of revenue forecast biases. Indeed, an optimistic estimation of government revenues is likely to have a positive impact on the debate on the budget. By such an optimistic view of future income streams, the common pool of resources seemingly expands. Consequently, more coalition members are able to adopt policies that satisfy their electorate, which eases the drafting of the budget. Increasing the common pool of resources by an optimistic assessment of future tax revenues could thus well be the key to prevent difficult budget negotiations. Since Alesina and Drazen (1991) state that large coalitions find it particularly hard to reach agreements, politically fragmented governments can be expected to be more optimistic about their tax revenues than single party governments. ${ }^{5}$

\section{Strategic use of debt}

Beside the (possibly subconscious) optimistic estimation of tax revenues under fragmented governments discussed in the previous two sections, there is also the possibility that politicians deliberately overestimate tax revenues. The reason is that incumbents are usually uncertain about their return to power following future elections. Given this uncertainty, they may be tempted to affect policies carried out by their successors through fiscal decisions made in the current legislative period (see e.g. Persson and Svensson, 1989; Alesina and Tabellini, 1990; Tabellini and Alesina, 1990). For example, "by leaving debt to the future, today's government can force its successor to 'pay the bills' and spend less on the public good that is worth nothing to today's government” (Alesina and Tabellini 1990, 409). ${ }^{6}$

These 'strategic use of debt' models offer another interesting framework to explain the differences between real and budgeted tax revenue - and why there may be a stronger bias towards overestimation in fragmented governments. In fact, whether or not the current government engages in such a strategic debt game depends on the likelihood of getting into office during the next period. Given that parties in a coalition are on average less certain of future power than parties that do not share power ${ }^{7}$, coalition governments are expected to be more sensitive to the strategic use of debt. Their shorter time horizon may leave them less worried about the negative effects of optimistic tax revenue estimations and more keen to limit the policy options of the ensuing governments. We thus expect fragmented governments to more strongly (and consciously) engage in 'cosmetic accounting' (by means of overestimating tax revenues) while drafting the budget. ${ }^{8}$

4 For generalizations of the argument and the implications of such a generalized "war of attrition" model on economic policy, see e.g. Bulow and Klemperer (1999) and Martinelli and Escorza (2004).

5 Note that, as before, no intention to overestimate tax revenues need be present (cfr. supra).

6 The empirical predictions from Alesina and Tabellini (1990) and Tabellini and Alesina (1990) differ from those by Persson and Svensson (1989). Indeed, the former predict a deficit bias irrespective of the incumbent's ideology, whereas the latter argue that only right-wing governments issue debt, whereas leftwing governments reduce debt in reply to electoral uncertainty. Pettersson-Lidbom (2001) finds empirical support for the latter model only in an analysis of Swedish local governments.

7 They not only have to 'win' the elections, but also survive the ensuing coalition negotiations (for a similar argument, see Ashworth et al., 2005b).

8 Note that incumbents are probably able to relatively adequately judge their chance of returning to power in Belgium. Firstly, elections at the various levels of government are held at different points in time such that electoral fortunes can (partly) be gauged from the electoral fate of one's party on other political levels. Secondly, Ackaert et al. (2001) show that most municipalities witness preliminary discussions (and even preliminary agreements) about coalition formation prior to the elections. In fact, with respect to the municipal 


\section{Institutional setting}

Our analysis concentrates on tax projections in Flemish municipalities. This locallevel context offers the advantage that municipalities have a homogeneous institutional context. Formal budget rules, electoral rules and so on are identical across municipalities, which allows us to focus on the effect of political fragmentation without the need to control for these intervening variables. However, prior to the empirical analysis, the present section wishes to familiarize the unacquainted reader with some crucial characteristics of Flemish local governments and their functioning. We more specifically draw attention to the local system of government (and the level of government fragmentation) (section 3.1), the budgetary process (section 3.2) and the revenue structure in Flemish municipalities (section 3.3).

\subsection{Local government system}

Local governments in Belgium (and thus also Flanders) have a parliamentary system consisting of the local council (the legislative body) and the College of Mayor and Alderman (the executive body). The number of seats in each of these bodies depends on the size of the municipality. While the College consists of 2 to 10 members, the council comprises of 7 to 55 politicians. These are elected once every 6 years and can be indefinitely re-elected (i.e. there are no term limits). The composition of the College is determined by the party (or parties) holding a majority position in the council. They appoint the alderman and propose a mayor from among their councillors (the mayor is then officially appointed by the King). Local power thus rests (nearly) completely in the hands of the parties holding a majority position in the local council.

Seats in the council are allocated using a system of proportional representation (PR), such that each party is allocated a certain number of seats in proportion to the votes it obtains in the elections. It is well established that PR-systems tend to generate more fragmented political landscapes. The number of parties competing in elections and in the government is generally larger than under plurality rule (Duverger, 1954/1972). Table 1 depicts the number (and share) of Flemish municipalities where the College of Mayor and Alderman consists of one, two, three or more parties (following the elections of 1988, 1994 and 2000). We also display the average number of parties that obtains representation in the College.

elections of 1994, they show that in $85,2 \%$ of the Flemish municipalities such preliminary discussions took place. Looking at the municipal elections of 2000, they find that in no less than $67,4 \%$ of the Flemish municipalities a preliminary agreement about the (possible) distribution of local power was reached prior to the elections. 
TABLE 1: Size of College of Mayor and Alderman in Flanders $(\mathrm{N}=308)$

\begin{tabular}{|c|c|c|c|}
\hline & $\mathbf{1 9 8 9 - 1 9 9 4}$ & $\mathbf{1 9 9 5 - 2 0 0 0}$ & $\mathbf{2 0 0 1 - 2 0 0 6}$ \\
\hline \multirow{2}{*}{1 party } & 140 & 120 & 96 \\
\hline \multirow{2}{*}{2 parties } & $45.5 \%$ & $39.0 \%$ & $31.2 \%$ \\
\hline \multirow{2}{*}{3 parties } & 136 & 149 & 162 \\
& $44.8 \%$ & $48.4 \%$ & $52.6 \%$ \\
\hline \multirow{2}{*}{+3 parties } & 27 & 31 & $14.0 \%$ \\
\hline Average number of parties & $5.8 \%$ & $8.1 \%$ & 7 \\
\hline
\end{tabular}

Note: Table taken from Ashworth et al. (2005a, 400).

From Table 1 it can be seen that, in each legislative period, more than $80 \%$ of the Flemish municipalities have a single party government or a two-party coalition government. However, the importance of single party governments decreases strongly over the period under study while the opposite is true for two-party coalitions. Indeed, in the first legislature (1989-1994) both groups are of approximately equal size (around 45\% of the Flemish municipalities). Since then, municipalities with two party coalitions have grown in importance (up to $52.6 \%$ in the current legislature) whereas those with one party majorities have dwindled to less than one third of all Flemish municipalities. The increasing level of political fragmentation over this period also shows from the fact that large coalitions (i.e. those holding three or more parties) are also becoming more prevalent. Indeed, the number of coalitions with three parties rose from the $8,8 \%$ in the $1989-1994$ period to $14 \%$ after the municipal elections of 2000. Moreover, the average number of parties in the college rises from 1,67 to 1,87 over the entire period. From these data, one could argue that the level of political fragmentation is rather low in Flemish municipalities. It has, however, been recurrently shown that it nonetheless has a significant impact on local fiscal policy (e.g. Ashworth and Heyndels, 2005; Ashworth et al., 2005a, b).

\subsection{Budgetary process}

The fiscal year runs parallel to the civil year in Belgium (from 1 January to 31 December). Prior to each fiscal year, the municipality must prepare a budget. This is important as no other expenditures but those ratified in the budget can actually take place (with minor exceptions in specific circumstances). In general, the first steps in the preparation of the budget are taken after summer recess in August or September. Each local authority's financial department then sets up a budget in order to match the municipality's administrative and political objectives. This draft is based on the individual budgets brought forward by the various alderman and is discussed by the College of Mayor and Alderman. The proposal of the overall budget that develops from these discussions is then brought before the local council for ratification. This in principle takes place on the first Monday of October (though only few municipalities actually meet this deadline).

Only when the budget is endorsed before 31 December, it can be executed. If local politicians do not reach agreement on next year's budget prior to 31 December, a specific regulation comes into force with the previous year's budget as a guideline. Specifically, the local government is only allowed to spend 1/12 of last year's budget per month until the new budget is approved. Moreover, no new projects can then be embarked on. Tax revenue projections used in the empirical analysis are taken from the budget as approved by the local 
council. ${ }^{9}$ Following the fiscal year, the annual account is drawn up. The collected local tax revenues we use in our analysis derive from this annual account.

As mentioned previously, local governments must adhere to a balanced budget rule. This rule, however, only relates to the budget and does not imply a statutory obligation to close the fiscal year with a balanced account. As such, the Flemish balanced budget requirements are rather weak, according to Poterba's (1995) categorization. After the budget is ratified, revenues (and to a lesser degree expenditures) may diverge from those recorded in the budget and lead to a deficit or a surplus ex post.

\subsection{Revenue structure}

The Flemish municipalities enjoy a far-reaching autonomy in their fiscal policies. As long as their initiatives are not prohibited explicitly by federal legislation, they are authorized to pursue any policy to promote the interests of their constituents - and to decide independently on the level and structure of revenues to finance these initiatives. The most important expenditures are public administration, public safety, education and social services. At the revenue side, grants from higher levels of government (which are for the most part unconditional), dividends from municipal associations in charge of electricity and gas distribution, and taxation are the most important sources of revenue. Taxation, the focal point of the current paper, generates the most important part of the Flemish municipalities' revenues (viz. over $47 \%$ of all revenues in 2002). Approximately $83 \%$ of this tax income derives from surcharge taxes on federal and regional taxes on immovable property (i.e. the local property tax) and labour (i.e. the local income tax). Importantly, the federal or regional governments collect both surcharge taxes and transfer these revenues to the municipalities. In addition, for each municipality they make a projection of expected revenues, which the municipalities quote in their budget. This implies that the local governments are not to be held accountable for any bias in these projections.

However, besides the surcharge taxes mentioned above, municipalities can (and do) also collect local taxes of which they set the tax base as well as the tax rate. In fact, the average Flemish municipality collects about 15 of such taxes and the most 'exotic' taxes can be found among the more than 100 local taxes that are currently in use: taxes on private swimming pools, on balconies, on transportation of drunken persons, on dogs, boats and so on. Important for our empirical analysis is that municipalities independently project revenues for these local taxes. Moreover, since revenues from grants are fixed by federal law (and depend on population size) and the municipalities receive a projection from higher-level governments for surcharge taxes, local tax revenues are the main part of local revenues for which the municipality must project revenues itself. Hence, if the local government is susceptible to make biased revenue projections, local tax revenue is the most accessible to do so. This is the reason why we focus on local tax revenues in the remainder of this paper.

\section{Empirical analysis}

To empirically assess the relation between government fragmentation and the forecast error in tax projections, we use a panel data set from 1992 to 2002 for 242 Flemish municipalities. Though there are 308 Flemish municipalities, data availability precludes the use of more than these 242 municipalities. This nonetheless leaves us with a large and

9 Importantly, the budget as approved (preferably) before 31 December need not be the final budget. In the course of the fiscal year, some modifications can or must take place because of technical reasons or to balance the budget when exceptional events impose additional expenditures. In our analysis, however, local tax revenue projections do not consider such modifications due to lack of data. 
previously unexploited dataset. The advantage of the dataset is that it comprises not only significant variation in the central explanatory variable (i.e. political fragmentation) over the municipalities cross-sectionally, but also over time (due to the incorporation of two elections within the time frame: 1994 and 2000). In section 4.1 we provide a detailed account of the model's specification and the measurement of our variables. Section 4.2 presents the methodology and empirical results.

\subsection{Model Specification}

We estimate the following multivariate model to test our predictions (subscripts $\mathrm{i}$ and $\mathrm{t}$ referring to municipalities and time respectively):

$$
\begin{aligned}
\text { DFCT }_{\mathrm{i}, \mathrm{t}}= & \mathrm{a}+\mathrm{b}_{1} \text { DFCT }_{\mathrm{i}, \mathrm{t}-1}+\mathrm{b}_{2} \text { DFCT }_{\mathrm{i}, \mathrm{t}-2}+\mathrm{b}_{3} \text { TAXP }_{\mathrm{i}, \mathrm{t}}+\mathrm{b}_{4} \text { TAXN }_{\mathrm{i}, \mathrm{t}}+\mathrm{b}_{5} \text { DEF }_{\mathrm{i}, \mathrm{t}-1} \\
& +\mathrm{b}_{6} \text { POP }_{\mathrm{i}, \mathrm{t}}+\mathrm{b}_{7} \text { POPGR }_{\mathrm{i}, \mathrm{t}}+\mathrm{b}_{8} \text { FIRMGR }_{\mathrm{i}, \mathrm{t}}+\mathrm{b}_{9} \text { TREND }_{\mathrm{t}}+\mathrm{b}_{10} \text { FRAG }_{\mathrm{i}, \mathrm{t}} \\
& + \text { year dummies }+\mathrm{e}_{\mathrm{i}, \mathrm{t}}
\end{aligned}
$$

Our dependent variable (DFCT) equals the ratio of projected to realized local tax revenue of municipality $\mathrm{i}$ in year $\mathrm{t}$ and is calculated as:

$$
\operatorname{DFCT}_{i, t}=\mathrm{BT}_{\mathrm{i}, \mathrm{t}} / \mathrm{CT}_{\mathrm{i}, \mathrm{t}}
$$

where: $\mathrm{BT}_{\mathrm{i}, \mathrm{t}}=$ budgeted local taxes of municipality $\mathrm{i}$ for year $\mathrm{t}$

$\mathrm{CT}_{\mathrm{i}, \mathrm{t}}=$ collected local taxes of municipality i for year $\mathrm{t}$

This variable can be interpreted as the percentage of budgeted revenues that is actually pocketed by the local government and is termed the degree of foresight of collected taxes (DFCT) in the remainder of the paper. When DFCT is higher (lower) than 1, tax revenues are overestimated (underestimated) in the municipal budget. As mentioned before, we only look at revenues from local taxes. As can be seen in Table A1 in appendix - where we provide summary statistics for all the variables in the model - Flemish municipalities have a tendency to (slightly) overestimate local tax income. On average, budgeted revenues from local taxes are about 5 percent higher than collected revenues from these taxes.

A lagged dependent variable is included in the model to account for possible slow adjustments in local government behaviour. We expect this variable to carry a positive sign indicating that over- or underestimates of tax revenues in any given year are not magically resolved in the following years. Preliminary work showed that two lagged terms of our dependent variable are necessary to remove all autocorrelation from the residuals of the estimation. We expect both these lagged terms to present a positive coefficient estimate, such that $b_{1}>0$ and $b_{2}>0$. Since last year's tax forecast error is likely to weigh more heavily on this year's forecast error compared to that two years before, we also hypothesize that $b_{1}>b_{2}$.

Before we discuss the central explanatory variable of the model (i.e. political fragmentation), we first briefly go into the various control variables we included based on findings in the preceding literature. Firstly, we control for the importance of local tax revenues (TAXP). This is operationalised as local tax revenues divided by total revenues. It varies between 0.75 percent and 37.64 percent with a mean value of 7.55 percent (see Table A1). In line with the tax technology function literature (e.g. Mayshar, 1991), we anticipate that municipalities deriving a larger share of their revenues from local taxation improve their tax administration performance. This increases collected revenues relative to budgeted revenues, such that we hypothesize a negative coefficient estimate on this variable $\left(\right.$ or $\left.b_{3}<0\right)$.

A second control variable takes into account the number of taxes a municipality levies (TAXN). This is operationalised as a simple count of all the different local taxes in a given 
year and from which revenues are generated. It is clear that a larger number of taxes tend to make the budgeting process more complex. More tax legislation has to be scrutinized by the local tax administration, more tax bases have to be determined and so on. In line with findings from the literature on securities analysts' revenue forecast accuracy (e.g. Duru and Reeb, 2002), we expect that this complexity of the local tax system is associated with more optimistic budgets, or $b_{4}>0$. The reason is that diversification adds to the unpredictability of income, which may well have an "incremental effect on optimism (...) due to additional opportunities for managerial discretion” (Duru and Reeb, 2002, 418).

Following Esteller-Moré (2004), we also control for the possibility that the tax administration's effort depends on the budgetary situation in the municipality. The more precarious this situation is, the higher the effort to collect tax revenues (and the stricter tax laws will be enforced). Therefore, we include the fiscal deficit as a share of total revenues incurred during the previous fiscal year (DEF). We expect Flemish municipalities (like their Spanish counterparts) to become more active in enforcing tax rules when facing a deficit during the previous year. Given that pocketed revenues then increase as budgeted revenues remain stable, we thus expect $b_{5}<0 .^{10}$

Next, population size (POP, in 1000 inhabitants) is introduced to control for the size of the municipality. This can have two opposing effects. On the one hand, it is likely to indicate more complexity and thus greater forecast difficulty. In line with the above argument, this is likely to lead to more optimistic estimations, such that $b_{6}>0$. It should be noted here that the correlation between population size and the number of local taxes in the municipality is moderately strong $(\mathrm{r}=0.43)$. On the other hand, larger municipalities may benefit from economies of scale. They tend to have a larger (tax) administration such that tax administration performance is likely to increase. This increases collected revenues relative to budgeted revenues, leading to a negative coefficient estimate on this variable (or $b_{6}<0$ ). Taking both effects together, the sign of $b_{6}$ is a priori uncertain.

We furthermore control for the impact of tax base changes. Since local taxes are levied on both inhabitants and firms, the evolution in the number of inhabitants (POPGR) and firms (FIRMGR) may affect the local tax revenue forecast error. These variables are measured as year-on-year growth rates in population size and the number of firms respectively. ${ }^{11} \mathrm{~A}$ negative coefficient is expected for both these variables. The reason is that inhabitants or firms leaving (entering) the territory stop (start) paying local taxes while the local government is unaware of the intention of individuals or firms to leave (enter) at the time of preparing the budget. Hence, a higher number of inhabitants or firms leaving (entering) decreases (increases) the amount of taxes collected by the municipality. As the amount of revenues as recorded in the budget remains fixed at the time of these population (or industrial) changes, a lower (higher) amount of collected revenues due to these changes leads to higher (lower) values of the dependent variable, such that $b_{7}<0$ and $b_{8}<0$.

The inclusion of a linearly increasing trend variable (TREND) accounts for the (slight) upward trend in the dependent variable. Moreover, a full set of year dummies has been included in the estimations to partial out common shocks to the municipal finances (e.g. due to macro-economic shocks or changes in federal legislation that affect local governments).

\footnotetext{
10 Esteller-Moré (2004) also includes grants as a share of total revenues to account for a possible reduction in tax enforcement when a larger part of income is obtained through grants from higher-level governments. We exclude this variable in the present analysis as its introduction in a model containing TAXP (i.e. the share of local tax revenues in the municipality's total revenues) led to significant multicollinearity problems. Inclusion of TAXP gave a better overall fit of the model, hence the choice for this variable in the final model.

11 Most local taxes are lump sum taxes. Hence, all inhabitants (and firms) must pay the same amount. As such, the change in the number of potential taxpayers provides an adequate proxy for the change of the tax base.
} 
To the extent that our control variables do not fully pick up these effects, year dummies capture them. ${ }^{12}$

Finally, we test our main hypothesis that fragmented governments have more optimistic tax revenue projections. This might be either unintentional (i.e. optimism to reduce cognitive dissonance) or purposeful overestimation (i.e. a strategic use of fiscal decisions). In both cases, a positive estimate of $b_{10}$ is expected. We introduce two different operationalisations for this variable (FRAG). The first - NUMCOAL - measures fragmentation as a simple count of the number of parties in the ruling coalition (i.e. in the College of Mayor and Aldermen). We also test for a possible non-linearity in the effect of fragmentation by including a squared term of this variable. Though there is no clear theoretical prediction with regard to this non-linearity, it would clearly be of interest to assess whether, say, three party coalitions are behaving significantly differently from, say, two party coalitions. The second operationalisation intends to gauge the latter effect in a more elementary way by introducing two dummy variables for two party coalition governments (TWOPART) and 'large' coalitions (i.e. coalitions with three or more parties, LARGE) - with single party governments as the rest category.

\subsection{Methodology and results}

It is well known by now that the standard approaches to panel data analysis are inappropriate in a dynamic setting. Both fixed and random effects estimators lead to biased and inconsistent estimation results in the presence of a lagged dependent variable (Baltagi, 1995). To remove this bias, it is necessary to provide a valid set of instruments for the lagged dependent variable. Arellano and Bond (1991) offer a solution to this problem by treating the model as a system of equations (viz. one for each time period) and developing a Generalized Method of Moments estimator that exploits the moment conditions for the equations in first differences. Specifically, the estimator is based on taking first differences of the model (to remove municipality-specific effects) and then instrumenting the lagged dependent variable in first differences with suitable lags of its own levels. In particular, values of the dependent variable lagged two periods or more can be used as instruments. The estimator developed by Arellano and Bond (1991) is generally called difference GMM (or GMM-DIF). It is ideal for short time series (such as ours) because the number of valid instruments grows with the number of years in the sample.

However, an important obstruction to using GMM-DIF is that the lagged values of the dependent variable may be only weak instruments in the differenced regression. This could lead to severe finite-sample bias, especially when the series is very persistent (see Blundell and Bond, 1998). Given this, we employ system GMM estimation (GMM-SYS; Arellano and Bover, 1995; Blundell and Bond, 1998). This method combines the moment conditions for the equations in first differences exploited in the GMM-DIF estimator with additional moment conditions for the equations in levels. The introduction of these additional moments increases the efficiency of the estimation. Note also that we use the one-step rather than the two-step variant of GMM-SYS. Although the latter is asymptotically more efficient, two-step GMM estimation is found to lead to significant downward bias in the estimated standard errors (Arellano and Bond, 1991; Blundell and Bond, 1998).

\footnotetext{
12 Unlike Young et al. (2001) and Bischoff (2004), we do not explicitly account for a possible election effect in the model. Though such effects would be picked up by the year dummies, including a dummy variable equal to one in the two election years in the sample (1994 and 2000) turns out to be insignificant once controlling for the upward time trend. The same holds when we model an election cycle by including a variable measuring the time to the next election (ranging from 5 in the first post-election year to 0 in election years) and its squared values.
} 
Table 2 provides the estimation results. Six sets of results are given, which differ only in their measurement of the (core) government fragmentation effect. Columns (1) and (2) provide the most general results and look for a linear effect of political fragmentation via NUMCOAL. In columns (3) and (4), we test for possible non-linearity in the fragmentation effect by adding the squared term of NUMCOAL. Finally, in columns (5) and (6), the effect of fragmentation is estimated in a more elementary way by including two dummy variables: TWOPART (which is 1 for two-party coalitions) and LARGE (which is 1 when the coalition consists of three or more parties). The even columns maintain only the statistically significant variables and as such provide a more efficient estimation - while taking care not to compromise the diagnostic tests reported at the bottom of Table 2.

TABLE 2: Estimation results using one-step system GMM (1992-2002)

\begin{tabular}{|c|c|c|c|c|c|c|}
\hline Variable & (1) & (2) & (3) & $(4)$ & (5) & (6) \\
\hline Intercept & $\begin{array}{c}0.537 * * \\
(2.55)\end{array}$ & $\begin{array}{c}0.456 * * * \\
(2.78)\end{array}$ & $\begin{array}{l}-0.015 \\
(-0.04)\end{array}$ & $\begin{array}{l}-0.007 \\
(-0.02)\end{array}$ & $\begin{array}{c}0.477 * \\
(1.90)\end{array}$ & $\begin{array}{c}0.433 * * * \\
(2.79)\end{array}$ \\
\hline DFCT $_{t-1}$ & $\begin{array}{c}0.281 * * * \\
(5.16)\end{array}$ & $\begin{array}{c}0.296 * * * \\
(6.55)\end{array}$ & $\begin{array}{c}0.256 * * * \\
(3.85)\end{array}$ & $\begin{array}{c}0.270 * * * \\
(5.29)\end{array}$ & $\begin{array}{c}0.253 * * * \\
(3.96)\end{array}$ & $\begin{array}{c}0.273 * * * \\
(6.32)\end{array}$ \\
\hline DFCT $_{t-2}$ & $\begin{array}{c}0.148 * * * \\
(3.38)\end{array}$ & $\begin{array}{c}0.147 * * * \\
(3.44)\end{array}$ & $\begin{array}{c}0.149 * * * \\
(2.85)\end{array}$ & $\begin{array}{c}0.153 * * * \\
(3.03)\end{array}$ & $\begin{array}{c}0.153 * * * \\
(3.06)\end{array}$ & $\begin{array}{c}0.158 * * * \\
(3.64)\end{array}$ \\
\hline TAXP & $\begin{array}{c}-0.035 * * * \\
(-2.61)\end{array}$ & $\begin{array}{c}-0.034 * * * \\
(-2.65)\end{array}$ & $\begin{array}{c}-0.041 * * \\
(-2.50)\end{array}$ & $\begin{array}{c}-0.041 * * * \\
(-2.72)\end{array}$ & $\begin{array}{c}-0.044 * * * \\
(-2.72)\end{array}$ & $\begin{array}{c}-0.040 * * * \\
(-3.15)\end{array}$ \\
\hline TAXN & $\begin{array}{c}0.026 * * \\
(2.52)\end{array}$ & $\begin{array}{c}0.025 * * * \\
(2.79)\end{array}$ & $\begin{array}{c}0.021 * \\
(1.66)\end{array}$ & $\begin{array}{c}0.025 * * \\
(2.42)\end{array}$ & $\begin{array}{l}0.014 \\
(1.13)\end{array}$ & $\begin{array}{c}0.023 * * * \\
(2.99)\end{array}$ \\
\hline $\mathrm{DEF}_{\mathrm{t}-1}$ & $\begin{array}{l}-0.008 \\
(-0.68)\end{array}$ & - & $\begin{array}{l}-0.008 \\
(-0.59)\end{array}$ & - & $\begin{array}{l}-0.003 \\
(-0.25)\end{array}$ & - \\
\hline POP & $\begin{array}{l}-0.001 \\
(-0.38)\end{array}$ & - & $\begin{array}{l}0.002 \\
(0.45)\end{array}$ & - & $\begin{array}{l}0.004 \\
(0.95)\end{array}$ & - \\
\hline POPGR & $\begin{array}{l}0.129 \\
(1.31)\end{array}$ & $\begin{array}{c}0.153 * \\
(1.67)\end{array}$ & $\begin{array}{l}0.092 \\
(0.76)\end{array}$ & - & $\begin{array}{l}0.056 \\
(0.47)\end{array}$ & - \\
\hline FIRMGR & $\begin{array}{c}0.037 * \\
(1.81)\end{array}$ & $\begin{array}{c}0.036 * \\
(1.79)\end{array}$ & $\begin{array}{c}0.044 * \\
(1.79)\end{array}$ & $\begin{array}{c}0.040 * \\
(1.69)\end{array}$ & $\begin{array}{c}0.042 * \\
(1.80)\end{array}$ & $\begin{array}{c}0.038 * \\
(1.90)\end{array}$ \\
\hline TREND & $\begin{array}{c}0.029 * * * \\
(3.73)\end{array}$ & $\begin{array}{c}0.028 * * * \\
(3.74)\end{array}$ & $\begin{array}{c}0.030 * * * \\
(3.16)\end{array}$ & $\begin{array}{c}0.025 * * * \\
(3.16)\end{array}$ & $\begin{array}{c}0.024 * * * \\
(2.63)\end{array}$ & $\begin{array}{c}0.023 * * * \\
(3.63)\end{array}$ \\
\hline NUMCOAL & $\begin{array}{c}-0.159 * * \\
(-2.12)\end{array}$ & $\begin{array}{c}-0.143 * * \\
(-2.05)\end{array}$ & $\begin{array}{l}0.617 \\
(1.34)\end{array}$ & $\begin{array}{l}0.589 \\
(1.53)\end{array}$ & - & - \\
\hline NUMCOAL $^{2}$ & - & - & $\begin{array}{c}-0.200 * \\
(-1.71)\end{array}$ & $\begin{array}{c}-0.191 * \\
(-1.90)\end{array}$ & - & - \\
\hline TWOPART & - & - & - & - & $\begin{array}{l}0.069 \\
(0.47)\end{array}$ & - \\
\hline LARGE & - & - & - & - & $\begin{array}{c}-0.327 * \\
(-1.95)\end{array}$ & $\begin{array}{c}-0.351 * * * \\
(-2.93)\end{array}$ \\
\hline $\begin{array}{c}\text { Year } \\
\text { dummies }\end{array}$ & Yes & Yes & Yes & Yes & Yes & Yes \\
\hline Sargan & $39.95(44)$ & $41.40(46)$ & $25.08(43)$ & $28.49(46)$ & $27.30(43)$ & $38.25(47)$ \\
\hline $\mathrm{AR}(1)$ & $-5.88 * * *$ & $-5.94 * * *$ & $-4.59 * * *$ & $-5.10 * * *$ & $-4.78 * * *$ & $-6.06 * * *$ \\
\hline $\mathrm{AR}(2)$ & -0.45 & -0.76 & -0.08 & -0.44 & -0.43 & -0.70 \\
\hline
\end{tabular}

Note: $\mathrm{N}=2178$; t-values between brackets; ${ }^{*}$ significant at $10 \%, * *$ at $5 \%$ and $* * *$ at $1 \%$. Sargan is the test for over-identifying restrictions and has a $\mathrm{Chi}^{2}$ distribution with $\mathrm{R}$ degrees of freedom ( $R$ being the number of instruments minus the number of estimated parameters). AR(1) and $A R(2)$ are the required tests for first- and second-order autocorrelation. None of these diagnostic tests indicates misspecification of the model. 
Let us first look at the results for our central variable, viz. government fragmentation. Even though all three quoted arguments suggest that government fragmentation is likely to lead to more optimistic tax revenue projections - whether consciously or not - our findings do not support this theoretical prediction. The overall effect is negative which indicates that the number of parties in the College of Mayor and Alderman reduces the share of collected revenues in the total budgeted revenues. When we take into account the possible nonlinearity, we find that two-party coalitions indeed are more optimistic than one-party governments (though this effect is not statistically significant). Thus, the negative effect is mainly driven by the larger coalitions. Especially coalitions with more than two parties are (much) more careful in their tax projections and - for a given level of pocketed revenues ex post - expect to receive less revenues. ${ }^{13}$

What might explain these deviant findings? One possible explanation is that it becomes more difficult to ease the war of attrition by enlarging the common pool through (possibly subconscious) optimistic estimations of future revenues when the number of coalition partners exceeds two. The reason is that the larger number of parties implies that the common pool should be enlarged more fervently to please all coalition partners. Nonetheless, there clearly is a limit to being optimistic - and believing in the attainment of this projected level of revenues. Thus, even though politicians are likely to select their sources of information to fit their desired beliefs (cfr. "cognitive dissonance" theory, Akerlof and Dickens, 1982), this is unlikely to lead to ever-increasing optimism without losing credibility about the budget towards the electorate, the opposition and the supervising provincial government.

The previous argument would explain the apparent non-linearity in the fragmentation effect, though not the strong downturn we observe for coalitions larger than two parties. In fact, we would still expect large coalitions to be more optimistic than one-party governments (though possibly less so than two-party governments) where this is clearly not the case in our data. Two alternative explanations do account for the negative effect observed for large coalitions. The first is that broad-based coalitions are more likely to follow fiscal policies representative of a larger part of the population (see e.g. Lijphart and Crepaz, 1991). They might thus be less prone to threats of minor interest groups, limiting increases in expenditures and thereby the need to present optimistic budgets. Note, moreover, that "an increase in the number of powerful groups [leads to] a dilution of power concentration" (Tornell and Lane, 1999, 32). Hence, increases in the number of coalition partners reduce the power of each of these in the fiscal appropriation process. This leads to lower levels of overspending when the number of coalition parties increases - thereby limiting the need to present optimistic budgets. The second possible explanation is that a higher number of coalition members increase the possibility that at least one of them participates in the next government. It would be hard to believe that current coalition members unanimously agree to reduce the policy options of the following government when at least one of them is likely to be seated in this government. Clearly, in this situation the strategic use of fiscal policy looses its 'attraction' (and overestimation of tax revenues may be reduced rather than increased).

It is of interest to mention at this point that Ashworth et al. (2005a, b) have previously also found a non-linear effect of government fragmentation on local government's (fiscal) decision-making. Especially interesting is the finding by Ashworth et al. (2005a) that longterm local public indebtedness in Flemish municipalities reaches a maximum for coalitions of two parties and that more fragmented governments outperform such two-party governments.

${ }^{13}$ The results from the two-step GMM variant are broadly comparable to those presented although - as would be expected - significance levels are strongly inflated. To compensate this problem, we also calculated a finite-sample correction to the two-step covariance matrix (derived by Windmeijer, 2005). Results using this correction are generally somewhat weaker than those presented, though the degree of foresight of tax revenues of coalitions with more than two parties remains significantly lower than that of less fragmented governments (results available upon request). 
Our analysis suggests that this result can be related to the more cautionary revenue forecasting behaviour of more fragmented governments in the Flemish setting.

Turning to the control variables, it can be seen that, with the exception of the variables that consider tax base changes, the estimated coefficients all have the expected sign. Firstly, both lagged dependent variables $\mathrm{DFCT}_{\mathrm{t}-1}$ and $\mathrm{DFCT}_{\mathrm{t}-2}$ are statistically significant in all equations. As expected, they have a positive coefficient indicating that local government behaviour is interdependent over time. Municipalities with high (low) ratios of budgeted to collected revenues are more likely to have high (low) values in following years. Also, last year's forecast error clearly weighs more heavily on this year's forecast error compared to that from two years before.

The effect of the share of local taxes in total revenues (TAXP) is statistically significant and in the expected direction. Indeed, municipalities deriving a larger share of their revenues from local taxation appear to increase their tax administration performance, which is in line with the tax technology literature (e.g. Mayshar, 1991). In addition, we find support for the hypothesis that increases in the complexity of the tax system - measured by the number of taxes in the municipality (TAXN) - lead to higher projected revenues compared to actually collected revenues (cfr. Duru and Reeb, 2002). Yet, and in contrast to findings by EstellerMoré (2004) on a sample of Spanish municipalities, we do not find that the tax administration's effort depends on the budgetary situation in the municipality. Specifically, the fiscal deficit as a share of total revenues (DEF) has no statistically significant effect, although the coefficient has the expected negative sign.

There is no effect from population size (POP). The coefficient estimate is never statistically significant and does not even display a consistent sign over the various estimates. Finally, while we expected that the growth of population (POPGR) and firms (FIRMGR) would negatively affect our dependent variable - because a growing (falling) tax base increases (decreases) collected revenues while leaving budgeted revenues unaffected - both variables have positive coefficients. The growth in the number of firms is even statistically significant in all equations. A possible explanation is that local governments increasingly overestimate expected firm movements. That is, the more firms move (ex post), the further the local government 'overshoots' the size of these movements in its (ex ante) expectations. As such, a positive coefficient estimate occurs. This tentative explanation calls, however, for further empirical analysis.

\section{Conclusion}

The present paper has its relevance for two research fields. On the one hand, it contained the first empirical analysis upon the relation between political fragmentation and fiscal policy that explicitly focuses on earlier stages in the fiscal process, i.c. the drafting of the budget. This extends previous research on the Weak Government Hypothesis that exclusively concentrated on actual revenue and/or spending levels and disregarded the potential influence of government weakness on the government's ability to (adequately) forecast its revenue and/or spending levels. On the other hand, analyses of the government's forecast accuracy have been focussing on technical aspects of the collection and budgeting process, but failed to consider political-economic factors (such as government fragmentation) as potential explanations. Our paper attempts to remedy both these deficiencies.

Based on three theoretical arguments we hypothesized that fragmented governments would (whether or not on purpose) be more likely to overestimate future revenue streams. First, such (over-)optimism allows for the higher spending levels generally associated with fragmented governments under the Weak Government Hypothesis. Secondly, it could be useful in alleviating a war of attrition during budget negotiations. Finally, overestimations of 
future revenues may be a conscious and strategic (ab)use of fiscal policy to restrain future governments (of which one may no longer be part).

Using data of 242 Flemish municipalities over the period 1992-2002, our results indicated that the level of political fragmentation indeed plays a role in revenue forecasting. Nonetheless, the findings did not support our theoretical predictions. In fact, our analysis disclosed that two party coalitions are slightly more optimistic than single party governments (though this effect was not statistically significant), while coalitions with at least three parties are less optimistic. This deviant finding may have multiple explanations. For example, it could be argued that broad-based coalitions are less prone to threats of minor interest groups, thereby reducing the need to present (over)optimistic budgets (cfr. Lijphart and Crepaz, 1991). Alternatively, larger coalitions may imply that at least one of its members participates in future governments, limiting the attraction of the strategic use of fiscal policy. Interestingly, however, our results are consistent with the evidence in Ashworth et al. (2005a) that, compared to single- and multi-party governments, two-party governments are associated with the highest levels of long-term local public indebtedness in Flemish municipalities. As such, our analysis suggests that the lower level of indebtedness of very fragmented Flemish local governments established in that paper can be related to their more cautionary revenue forecasting behaviour. Clearly, future research will need to determine whether a similar relation also exists in different settings and/or at various levels of government and, if not, what political and/or institutional elements drive this difference. 


\section{References}

Ackaert, J., De Winter, L. and Dumont, P., 2001, De vorming van lokale bestuursmeerderheden, Tijdschrift van Dexia Bank 216, 29-35.

Akerlof, G. A. and Dickens, W. T., 1982, The economic consequences of cognitive dissonance, American Economic Review 72(3), 307-319.

Alesina, A. and Drazen, A., 1991, Why are stabilizations delayed?, American Economic Review 81, 1170-1188.

Alesina, A. and Tabellini, G., 1990, A positive theory of fiscal deficits and government debt, Review of Economic Studies 57, 403-414.

Alt, J.E. and Lowry R.C., 1994, Divided government, fiscal institutions and budget deficits: evidence from the States, American Political Science Review 88(4), 811-828.

Arellano, M. and Bond, S., 1991, Some tests of specification for panel data: Monte Carlo evidence and an application to employment equations, Review of Economic Studies 58, 277-297.

Arellano, M. and Bover, O., 1995, Another look at the instrumental variable estimation of error-components models, Journal of Econometrics 68, 29-51.

Ashworth, J. and Heyndels, B., 2005, Government fragmentation and budgetary policy in "good" and "bad" times in Flemish municipalities, Economics and Politics, forthcoming.

Ashworth, J., Geys, B. and Heyndels, B., 2005a, Government weakness and local public debt development in Flemish municipalities, International Tax and Public Finance 12(4), 395422.

Ashworth, J., Geys, B. and Heyndels, B., 2005b, Determinants of tax innovation: The case of environmental taxes in Flemish municipalities, European Journal of Political Economy, forthcoming.

Auerbach, A. J., 1995, Tax projections and the budget: lessons from the 1980's, American Economic Review 85(2), 165-169.

Auerbach, A. J., 1999, On the Performance and Use of Government Revenue Forecasts, National Tax Journal 52(4), 767-782.

Baltagi, B., 1995, Econometric Analysis of Panel Data, London: John Wiley.

Bischoff, I., 2004, Tax projections in German states - manipulated by opportunistic incumbent parties?, paper presented at the annual EPCS Conference, Berlin, April 2004.

Blundell, R. and Bond, S., 1998, Initial conditions and moment restrictions in dynamic panel data models, Journal of Econometrics 87, 115-143.

Borge, L.-E., 2005, Strong politicians, small deficits: Evidence from Norwegian local governments, European Journal of Political Economy 21(2), 325-344.

Bulow, J. and Klemperer, P., 1999, The generalised war of attrition, American Economic Review 89, 175-189.

Congressional Budget Office, 1997, An economic model for long-run budget simulations, Washington D.C., July 1997.

Duru, A. and Reeb, D. M., 2002, International diversification and analysts' forecast accuracy and bias, Accounting Review 77(2), 415-433.

Duverger, M., 1954/1972, Political parties: their organization and activity in the modern state, Methuen, London.

Esteller-Moré, A., 2004, Is there a connection between the tax administration and the political power?, IEB Working paper.

Hettich, W. and Winer, S., 1984, A positive model of tax structure, Journal of Public Economics 24, 67-87.

Hettich, W. and Winer, S., 1988, Economic and political foundations of tax structure, American Economic Review 78(4), 701-712. 
Hunter, W. J. and Nelson, M. A., 1995, Tax enforcement: a public choice perspective, Public Choice 82, 53-67.

Lijphart, A. and Crepaz, M.M.L., 1991, Corporatism and consensus democracy in eighteen countries: Conceptual and empirical linkages, British Journal of Political Science 21, 235256.

Martinelli, C. and Escorza, R., 2004, When are stabilizations delayed? Alesina-Drazen revisited, Instituto Tecnológico Autónomo de México, mimeo.

Mayshar, J., 1991, Taxation with Costly Administration, Scandinavian Journal of Economics 93(1), 75-88.

Perotti, R. and Kontopoulos, Y., 2002, Fragmented fiscal policy, Journal of Public Economics 86, 191-222.

Persson, T. and Svensson, L. E. O., 1989, Why a stubborn conservative would run a deficit: policy with time-inconsistent preferences, Quarterly Journal of Economics 104(2), 325345.

Petterson-Lidbom, P., 2001, An empirical investigation of the strategic use of debt, Journal of Political Economy 109(3), 570-583.

Plesko, G. A., 1988, The accuracy of government forecasts and budget projections, National Tax Journal 41(4), 483-501.

Poterba, J. M., 1994, State responses to fiscal crises: the effects of budgetary institutions and politics, Journal of Political Economy 102(4), 799-821.

Poterba, J. M., 1995, Balanced budget rules and fiscal policy: evidence from the States, National Tax Journal 48(3), 329-336.

Ricciuti, R., 2004, Political fragmentation and fiscal outcomes, Public Choice 118, 365-388.

Roubini, N. and Sachs, J., 1989a, Government spending and budget deficits in the industrial countries, Economic Policy 8, 99-132.

Roubini, N. and Sachs, J., 1989b, Political and economic determinants of budget deficits in the industrial economies, European Economic Review 33, 903-938.

Rumi, C., 2004, Political Determinants of Fiscal Performance for the Argentine Provinces, paper presented at the annual PCS Conference, Baltimore, March 2004.

Tabellini, G. and Alesina, A., 1990, Voting on the budget deficit, American Economic Review 80(1), 37-49.

Tornell, A. and Lane P.R., 1999, The voracity effect, American Economic Review 89(1), 2246.

Tullock, G., 1959, Problems of majority voting, Journal of Political Economy 67(6), 571-579.

Velasco, A., 1999, A model of endogenous fiscal deficits and delayed fiscal eforms, in Fiscal Institutions and Fiscal Performance (NBER Conference Report), J.M. Poterba and J. Von Hagen (eds.), University of Chicago Press, Chicago, 37-57.

Velasco, A., 2000, Debts and deficits with fragmented fiscal policymaking, Journal of Public Economics 76, 105-125.

Volkerink, B. and de Haan, J., 2001, Fragmented government effects on fiscal policy: new evidence, Public Choice 109, 221-242.

Weingast, B. R., Shepsle, K. A. and Johnsen, C., 1981, The political economy of benefits and costs: a neoclassical approach to distributive politics, Journal of Political Economy 89(4), 642-664.

Windmeijer, F., 2005, A finite sample correction for the variance of linear efficient two-step GMM estimators, Journal of Econometrics 126, 25-51.

Young, M., Reksulak, M. M. and Shughart, W. F., 2001, The Political Economy of the IRS, Economics and Politics 13, 201-220. 
Appendix 1

Table A1: Summary statistics

\begin{tabular}{|l|c|c|c|c|}
\hline Variable & Mean & $\begin{array}{c}\text { Standard } \\
\text { deviation }\end{array}$ & Minimum & Maximum \\
\hline TRFA & 1.048 & 0.207 & 0.261 & 2.865 \\
\hline TAXP & 7.559 & 4.779 & 0.745 & 37.644 \\
\hline TAXN & 15.091 & 7.262 & 2 & 46 \\
\hline DEF & 6.632 & 7.778 & -20.145 & 41.059 \\
\hline POP & 20.529 & 34.450 & 0.963 & 465.783 \\
\hline POPGR & 0.436 & 0.623 & -3.216 & 3.531 \\
\hline FIRMGR & 1.176 & 2.617 & -71.161 & 12.614 \\
\hline NUMCOAL & 1.734 & 0.714 & 1 & 5 \\
\hline ENPG & 1.559 & 0.575 & 1 & 4.481 \\
\hline
\end{tabular}

